УДК 7.01

DOI 10.18413/2712-746X-2020-44-2-289-298

\title{
Визуальное восприятие искусства как первый шаг \\ В познании культурно-мировоззренческой основы цивилизации
}

\author{
Лопин Р.A. \\ Белгородский государственный национальный исследовательский университет, \\ Россия, 308015, г. Белгород, ул. Победы, 85 \\ E-mail: lopin@bsu.edu.ru
}

\begin{abstract}
Аннотация. Актуализированы проблемы бережного отношения к визуально-художественным образам традиционной культуры, которые неразрывны с духовными основами формирования культурно-цивилизационного пространства. Показано, как человек в культурно-цивилизационном пространстве соединяется с окружающими его предметами материальной культуры не только по принципу определения их утилитарных качеств, но и в естественном чувстве гармонии и красоты окружающего мира, выражающего духовные идеалы культуры. Они являются фактором выражения и формирования мировоззренческих основ человека, ей принадлежащего, от которых напрямую зависят положения, принятые для руководства в его жизни, его убеждения: социальные, политические, религиозные и др. Данный фактор исторически свойственен процессу культурной идентификации человека и присущ любой цивилизации.
\end{abstract}

Ключевые слова: культура, цивилизация, искусство, религия, православие, история, храм, икона, календарь, образ, символ, Россия.

Для цитирования: Лопин Р.А. 2020. Визуальное восприятие искусства как первый шаг в познании культурно-мировоззренческой основы цивилизации. NOMOTHETIKА: Философия. Социология. Право. 45 (2): 289-298. DOI 10.18413/2712-746X-2020-44-2-289-298

\section{Visual perception of art as the first step in the knowledge of the cultural and ideological basis of civilization}

\author{
Roman A. Lopin \\ Belgorod National Research University, \\ 85 Pobeda St, Belgorod, 308015, Russia \\ E-mail: lopin@bsu.edu.ru
}

Annotation. The problems of careful attitude to the visual and artistic images of traditional culture, which are inseparable from the spiritual foundations of the formation of cultural and civilizational space, are actualized. It is shown how a person in the cultural and civilizational space connects with the surrounding objects of material culture not only by the principle of determining their utilitarian qualities, but also in a natural sense of harmony and beauty of the surrounding world, which expresses the spiritual ideals of culture. They are a factor in the expression and formation of the worldview foundations of a person belonging to it, which directly affect the provisions adopted for guidance in his life, his beliefs: social, political, religious, etc. This factor is historically inherent in the process of cultural identification of a person and is inherent in any civilization.

Keywords: culture, civilization, art, religion, Orthodoxy, history, temple, icon, calendar, image, symbol, Russia. 
For citation: Lopin R.A. 2020. Visual perception of art as the first step in the knowledge of the cultural and ideological basis of civilization. NOMOTHETIKA: Philosophy. Sociology. Law series. 45 (2): 289298 (in Russian). DOI 10.18413/2712-746X-2020-44-2-289-298

Культура любой цивилизации лучше всего раскрывается в памятниках искусства, ее олицетворяющих. Они повествуют об истории, культурной целостности и самобытности цивилизации, открывают основы культурно-исторического единства общности народов, ее составляющих, - духовно-мировоззренческие принципы, формирующие традиции ее культуры. Специфике или отличительным, характерным особенностям цивилизаций, составляющих единое мировое цивилизационное пространство, присуще собственное выражение их духовного мира или метафизического начала в материальном воплощении, в способе и уровне овладения природным пространством, его художественном преобразовании.

Генезис цивилизаций в истории тесно сопряжен с религиозным мировоззрением человека. Религия и сегодня играет важную роль в определении характера той или иной цивилизации [Кин, 2006]. В большей степени мировые религии по сегодняшний день регламентируют порядок развития глобального цивилизационного пространства, определяя особенности локальных цивилизаций, традиционность их культур. Историческое происхождение культур, впоследствии в своем развитии культурно-исторических типов, их отличительные особенности сформировались в процессе духовного поиска человека. Само понятие культуры изначально ориентирует на внутренний духовно-мировоззренческий уклад человеческого естества [Спекторский, 2013, с. 33].

В современном мире можно выделить существование следующих цивилизаций: I - Евроатлантическая (чаще ее называют Западной) цивилизация, II - Русская (Восточнохристианская или Православная) цивилизация, III - Исламская цивилизация, IV - Восточная цивилизация [Переслегин, 2005, с. 102]. Они имеют свой «тип верования», который определяет в них аксиологию духовно-нравственной жизни человека с момента их возникновения и в процессе последующего развития, и воплощают в себе совокупный духовный опыт человечества.

Каждая культурно-цивилизационная конфигурация как внешнее очертание в своем пространстве во взаимном расположении предметных образов - это тип культуры или «вторая природа», реализовавшаяся в человеческой истории. Такая конфигурация закреплена в особых символических образах. В них локальные культуры неповторимы в реализации через искусство духовно-ценностных принципов своего существования, в визуализации которых, как представлении в форме, удобной для зрительного восприятия этого образа, каждая из цивилизаций в многообразии мирового пространства узнается, раскрывается. Цивилизация характеризует себя в собственном мировоззренческом идеале как форме отражения объективной действительности ее мироустройства, выраженном в искусстве с позиции определенного эстетического созерцания человека, ее представляющего.

Искусство как форма воспроизведения образов, истолкования жизни и ценностей культуры в создании эстетически воздействующих объектов может восприниматься в историческом процессе как определенная система их воспроизводства и функционирования в обществе, как система эстетических ценностей, обеспечивающая понимание духовномировоззренческой аксиологии культуры в целом [Культурология..., 1996, с. 552]. Оно, будучи высшим проявлением творческой самореализации человека, в практикоматериальном воплощении духовной культуры раскрывает ее тип и характер в созидании и преобразовании материала и выражается в архитектуре, живописи и многих других его видах. История развития искусства характеризуется большим многообразием форм. Они 
неповторимы и отражают определенное отношение человека к миру, к самому себе [Спекторский, 2013].

Примером визуализации цивилизаций, их художественного воплощения в символических образах искусства являются памятники традиционных культур.

Так, например, художественные образы культуры индуизма включают в себя знаменитые мандиры (храмы) индуизма - Береговой храм семи пагод (Махабалипурам, Индия, VII в.), Скальный храм Кайласа - Кайласанатха (Эллора, Западная Индия, VIII в.), Храм солнща - Конарак, (Орисса, Восточная Индия, ХІІІ в.), Великий храм (Танджавур, Южная Индия, XI в.), Гопура - Храм Минакши (Мадурай, Южная Индия, XII-XIII в.) и т.д.; художественное изображение индуистских богов - Брахма, Вишну (десять инкарнаций Вишну), Шива-Натарджа (Владыка танца) и их атрибуты; художественное изображение богинь индуизма - Лакшми (богиня богатства, жена Вишну), Сарасвати (богиня знания, дочь Брахмы), Кали (богиня разрушения, двойник Шивы); художественные изображения множества божеств индуизма (индуизм как любая языческая культура имеет почти бесконечное число божеств, многие из которых женского пола). Все они имеют мужские и женские качества, а также сложные атрибуты - Индра (бог войны и дождя, сидящий на слоне), Агни (бог огня с двумя головами, отвечающими за домашний и жертвенный огни, иногда в сопровождении барана), Дурга (мать-богиня и истребительница демонов), Бхикшатана (обнаженный отшельник с котелком для подаяний), Парвати (благодетельная мать и жена Шивы), Ардханаришвара (владыка, который является наполовину женщиной) [Наглядно о религиях, 2000; Самсонова, 2017] и др.

Художественные образы культуры буддизма включают в себя буддийские храмы китайская пагода, вад (Таиланд), шукуто - японский храм, дагоба - ступа-реликвалий (Шри-Ланка) - имеющие отличительные особенности не только в своей архитектурной композиции, но и в символике; художественные изображения Бодхисаттвы - «просветленной сущности» - в буддизме-махаяна Авалокитешвара, в тибетской мифологии Тара (женский аналог Авалокитешвары), в буддизме-махаяна Манджушри, Амитаба (Амида), будда «бесконечного света», Майтрейя, грядущий будда; символические статуи и образы Будды Будда в позе лотоса с руками в положении поучения, Истощенный Сиддхартха Гаутама, Амида, будда бесконечного света (жизни), Японский Будда, одетый монахом, Будда в полной позе лотоса для медитации [Наглядно о религиях, 2000; Емохонова, 2007] и др.

Художественные образы ислама включают в себя в храмовой архитектуре мечети, например, «Купол скалы» (Иерусалим), Бад-шахи-масджид (Индия), Большая мечеть в Самарре (Ирак) и м.д.; минареты (они отражают и своеобразный инструментарий звукосферы исламской цивилизации); искусство каллиграфии [Наглядно о религиях, 2000; Буркхардт, 2009] и др.

Кроме того, духовное начало любой цивилизации имеет отражение и в других художественных проявлениях собственной культуры, начиная с геральдики государств, ее представляющих, и заканчивая символически-художественным бытоустройством народов, входящих в ее состав, в том числе в хронологии летоисчесления - календаре. Визуальные символы цивилизации раскрывают признаки объективной ее общности, нашедшей выражение в общих фундаментальных чертах ментальности социума, которые в большей мере обусловлены духовно-религиозным ее началом. Художественно воплощенные в преобразованной материи, они понимаются через раскрытие духовных основ цивилизации, духовного, надфизического, метафизического начала ее культуры. В рамках цивилизации на метафизическом начале культуры формируется определенный набор и иерархия ценностей - система онтолого-метафизической аксиологии, которая выступает в качестве наиболее высокого уровня социально-культурной регуляции, где предметы материальной культуры - явление образов культуры духовной, выражение коллективного духа народа, ее представляющего. 
По этой причине исторические корни возникновения цивилизаций имеют непосредственное отношение к развитию духовной культуры в истории человечества, что необходимо учитывать при рассмотрении их своеобразия в материальной, духовной и социальной жизни. Так, при рассмотрении истории русской цивилизации решающую роль в понимании ее культуры имеет ее духовно-онтологическая связь с историей христианской цивилизации по той причине, что Русь на определенном этапе своего развития стала частью христианского цивилизационного пространства, в истории которого она неотделима от истории Православия.

Для русской культуры с момента становления русской государственности на протяжении всей истории было свойственно единство национального жизнестроительства и начала религиозного аскетизма, как принципа жизнедеятельности русского народа, формирующего саму культуру России. В ней высшие образцы художественного творчества включаются в процесс формирования собственной культурно-цивилизационной конфигурации, которая отражает духовное развитие сознания народа, их создающего, являясь образным воплощением его идеалов, мировоззрения, самосознания.

Эстетика таких символико-визуальных образов, как специфическое проявление ценностного отношения человека к миру, содержит в себе принципы морали как высшего проявления этических норм общежития, коллективное мироощущение, усвоенные критерии добра и зла, шкалу жизненных ценностей, веры в высочайший идеал и смысл жизни. В соблюдении этих принципов в художественном творчестве русского народа заложена целостность его культуры. Эта целостность сформировала национально-культурную ментальность - глубинную основу характера и поведения человека, принадлежащего к ней. В своем развитии образность искусства в таком случае отражает движение к истине, освоение ее и воплощение в культуре как образе жизни, идею исторического движения - поступательного развертывания истории - христианской историософии.

Историософия как понимание истории, нашедшая выражение в художественных символах как смыслообразах русской культуры, открывает суть неразрывности составляющих элементов христианской культуры [Новоселов, 2004]. Она содержит в себе три основных элемента: догматический, мистический, этический, которые определяют ее сущность как культуры, имеющей метафизическое начало. Исключение в ней одного из них приводит к неполноте или искажению не только христианства как мировоззренческой основы, но и самой культуры, какою в неискаженном виде является культура русского народа, русской цивилизации. Эти элементы в ней всегда понимались следующим образом: догматический - знание о Боге; мистический - знание Бога; этический - следование Богу.

Символом культуры русской цивилизации стал символ Воскресшего Бога - Христа, в ставрографии раскрывающий путь преображения мира, человека [Цеханская, 2013]. Этот символ бытия русского человека, который отражает в высшем проявлении смысловой фундамент русской культуры, духовное состояние русского человека, его мировоззрение, понимание им добра и зла, красивого и безобразного - аксиома православия в русской культуре [Русский крест..., 2006]. Он вошел в ставрографию и историю символики под названием «Русский-православный» [История развития..., 1997, с. 17] шестиконечный крест, оно и сегодня сохраняется в энциклопедической литературе по символике. Он стал вместе с «двуглавым орлом», символом цивилизационной преемственности Русью восточного христианства из Византии, в геральдике России онтологическим образом культуры, которая имеет характерные для нее черты: христоцентричности, Новозаветного начала, где Христос - единственное «средство» ипостасного соединения Божественной и человеческой природы; триадоцентричности, ипостасийности Триединого Бога - Отца, Сына и Святого Духа; иерковноцентричности, неотъемлемости Христа и Церкви. В ней материальная культура и внешнее украшение жизни не входили в непосредственные цели. Скорее, сотериологические требования подобной культуры регламентировали подчинение материальных потребностей духовным. В ее системе основной целью жизни человека яв- 
лялось душеспасение. Однако устремление к высшему идеалу в такой системе духовного развития стало свойственным стремлением и в бытоустройстве как преображении мира в высшем творческом порыве культурно-художественного воплощения. Историческое наследие сотериологии культуры Древнего Египта нашло выражение в грандиозности образов духовного устремления египтянина - пирамидах. В русской традиции духовные идеалы воплощались в храмовом зодчестве, синтезируя в себе все достижения русского искусства.

Храм в процессе формирования христианской культуры, как символическое воплощение Церкви - духовного единения христиан во Христе, восходит к ветхозаветному периоду истории человечества, к Скинии пророка Моисея и Храму царя Соломона, к новозаветному периоду становления христианской цивилизации на развалинах языческого Рима, к раннехрстианской духовной культуре - периоду развития храмового устройства, живописи, символики. В истории развития храмостроения на западе и востоке христианской цивилизации по историческим причинам под влиянием их собственных культур и видения христианства сложились разные типы храмового зодчества.

На западе храм, вобрав в себя «базиличную» (базилика греч. «царский дом» большое общественное здание, возводившееся в центре древнеримских городов, в котором проходили собрания, совершались суды, заключались торговые сделки) архитектурную схему устройства здания, приспособленную ранним христианством для богослужения, в большей степени сохранив генетическую преемственность Рима как законодательного центра цивилизации, сохранил в себе статику античного его величия. Рим «папской власти» довольно ярко проступает в основных стилях храмостроения, позднее получивших распространение в западноевропейской культуре: романском, готическом и возрождения. Все они, несмотря на свою внешнюю разность, отражают сущность западной ментальности - глобального идеологического центра [Любимов, 1976].

В восточнохристианском зодчестве динамика поиска художественного воплощения сложившихся церковных символов обусловила появление в нем, кроме «базиличной», разных форм храма уже в византийский период: храм в виде круга, равностороннего креста, прямоугольника, близкого к квадрату. Каждая из форм в храмовом зодчестве получила символическое значение: «Церковь - корабль спасения», «Крест Христов», «вечность, бесконечность» и т.д. Сам храм, увенчанный крестом, стал символом прославления Христа. В византийском храмостроении венцом символики прославления Христа стала крестово-купольная конструкция храма. Она воплотила в себе и во внешнем облике, и во внутреннем содержании главную идею христианства - нисхождения к человеку Бога, смысла человеческой истории как пути преображения в Боге, вселенскости Церкви как знамения всего мироздания во главе с Богом-Творцом. Святая София Константинопольская визуализация такого знамения - Вселенско-Соборного Царьграда [Борзова, 2002].

С принятием христианства на Руси храмы становятся сосредоточием ее культуры, центром любого поселения русского человека, что обусловило зарождение русской церковной архитектуры как символа христианского мира, органически включающего Русь во вселенское христианство. Воздвигнутые храмы служили этой цели, ориентируя сознание русского человека через литургически опытную жизнь, определяя дальнейшее развитие его самосознания - причастности к христианскому миру, что стало отправной точкой в развитии русской культуры, русского искусства. Они посвящались Христу Спасителю, Богородице, Живоначальной Троице или святым.

София Константинопольская стала образцом храмостроения для Руси. По образу Софии Константинопольской строились главные храмы древнерусских культурных центров - София Киевская, София Новгородская, София Полоцкая, в чем выражалась идея духовного единства русской земли.

Несмотря на то, что древнерусскому храмовому зодчеству присущи многие черты храмостроения Византии и европейских стран, в нем сложились достаточно яркие особен- 
ности самостоятельного творчества и поисков русских зодчих, нашедшие отражение в конструкциях, во внешнем и внутреннем декорировании храма собственно как культурноцивилизационного явления. Храм в подобном явлении, раскрывая свою культурную принадлежность, символизировал и раскрывал саму сущность русской цивилизации во всей исторической динамике, которую можно рассмотреть по известным памятникам: КиевоНовгородской Руси - «Десятинная» иерковь (к сожалению, на сегодняшний день не сохранившаяся), Спасо-Преображенский собор в Чернигове, Собор Святой Софии в Киеве, Золотые ворота в Киеве с Благовещенской иерковью (образ Золотых Ворот Константинополя), Собор Михаила Златоверхого в Киеве, Церковь Параскевы Пятнищь в Чернигове, Софийский собор в Новгороде, Николо-Дворищенский собор Новгорода, Георгиевский собор Юрьева монастыря, Рождественский собор Антониева монастыря, Церковь Федора Стратилата по Ручью, Церковь Спаса на Ильине улище; Владимиро-Суздальской земли Церковь Бориса и Глеба в Кидекше, Спасо-Преображенский собор в ПереславлеЗалесском, Успенский собор во Владимире, Церковь Покрова на Нерли; Московской Руси Успенский собор Московского Кремля, Благовещенский собор Московского Кремля, Архангельский собор Московского Кремля, Церковь прп. Иоанна Лествичника, Собор Василия Блаженного, Церковь Вознесения в Коломенском, Церковь Преображения в селе Остров, Воскресенский собор Новоиерусалимского монастыря, Церковь Рождества Богородиць в Путинках; Санкт-Петербурга - Петропавловский собор, Свято-Троиикий собор Александро-Невской лавры, Церковь Рождества св. Иоанна Предтечи, Князь-Владимирский собор, Николо-Богоявленский собор, Исаакиевский собор, Казанский собор, Храм Воскресения Христова. Все эти памятники как объекты изучения культурного наследия углубляют знания об исторической эпохе их создания, духовной культуре, искусстве, развитии строительной техники, открывают возможность зрительного представления - визуализации метафизики русской цивилизации.

Безусловно, центром визуализации русского мира является Московский Кремль, а позднее и Храм Христа Спасителя - символы России. Первый в истории России, сформировавшись как духовно-политический центр, стал ее «сердцем», первопрестолом страны (отсюда престольный град, столица). В своей архитектурной композиции, в своей православной символике Московский Кремль стал образом алтаря «русского Царьграда» «Третьего Рима» и «Второго Иерусалима», напоминая золотом своих куполов зажженные свечи, идею молитвенного предстояния Руси в «Граде Божием» - ее столице. В Московском Кремле (в Успенском соборе - Московской Софии) хранились знаковые предметы мировой и русской истории, такие православные святыни, как риза Господня, гвоздь, которым был прибит ко Кресту Спаситель, десница апостола Андрея Первозванного, нательный крест Константина Великого, «Мономахов трон» и многое др.

Второй, Храм Христа Спасителя, построенный русским народом в благодарность за заступничество Всевышнего за Россию в критический период ее истории, - памятник мужества русского народа в борьбе с наполеоновским нашествием 1812 г. [Храм Христа Спасителя..., 1993] в своей истории стал не только главным храмом Русской Православной Церкви, храмом-памятником, «храмом-мучеником» [там же], но и символом возрождения России, сохранения русской цивилизации.

Параллельно с художественным образом храма - метафизике, воплощенной в камне, - в русской культуре развивалась иконография, воплощающая богословскодогматическое учение христианской веры в красках. Она внесла огромный вклад в процесс визуализации духовного идеала русской культуры, раскрытие духа сознания русского человека, выработав новые формы художественного воплощения духовной реальности.

Иконопись нигде, как в русской культуре, не достигла такого высокого развития, не создала такое количество шедевров, не стала таким излюбленным видом изобразительного искусства для народа на протяжении многих столетий, как в России [Цеханская, 2013 , с. 95]. Для русской иконописи характерны и свой способ отражения жизни, и свои 
живописные приемы, и свой язык - свои секреты мастерства, привнесенные в церковную живопись русскими иконописцами.

Икона в культурном пространстве русской цивилизации - явление повсеместное: в монастырях, интерьерах храмов, для церковных служб (выносные, аналойные, иконы-мощевики), венчальные и для отпевания, домовые (для домашних иконостасов), именные, семейные, мерные (особый вид иконы, которая пишется по «размеру», по росту новорожденного), иконы-ладанки для ношения, вратарные и т.п., дающее целостное представление о мировоззренческих идеалах русского человека. Для него иконографический образ был источником познания смысла существования человека [Трубецкой, 1993], общества и мира в целом.

Многовековая история иконописания началась с первых изображений Иисуса Христа, пройдя сложный путь своего становления от создания первых символических изображений Иисуса Христа в раннехристианский период до формирования иконографических образов не только Христа, но и Триединого Бога, Богородицы, святых, отражая в себе Священное Писание и Священное Предание Церкви. Оно выработало правила, по которым пишутся иконы, - иконописный канон.

Изображение Христа в русской иконографии, следуя каноническому правилу письма, включает в себя оглавное, оплечное, поясное его изображения, а также изображение во весь рост. Христоцентричность русского сознания в ней выразилась в таких образах, как Спас Нерукотворный (Спас на чрепии и Спас на убрусе), Пантократор, Господь на престоле, Спас в Силах, Спас Еммануил.

Воплощение триадоцентричности русской культуры наиболее ярким образом было осуществлено в религиозно-мистическом символизме иконы «Троица» Андрея Рублева. Она, являясь величайшей святыней русского народа, символом русской культуры, православной цивилизации, олицетворяет собой наивысшее ее достижение в художественной культуре. Появление «Троицы» связано с отождествлением православной державы - России с центром вселенского православия, с самосознанием русской цивилизации, имеющей отличия от любой другой (католико-протестантской или магометанской и т.п.) цивилизации, с русским центризмом, вобравшим в себя христианское миссианство, став лучшим образом живописи Московской Руси на рубеже XIV-XV вв., живописным синонимом всей средневековой русской культуры. Сюжет «Троицы» богословски связует ветхозаветные события с новозаветными, открывает историческую преемственность новозаветной культуры с актом творения человечества, связь с его Творцом, что раз и навсегда утверждает в русской культуре идеал истины (не случайно с 1868 г. Мамврийский дуб - историческое свидетельство явления Троицы - стал достоянием Русской Духовной Миссии). Лица Святой Троицы в ней: Бог Отец, Бог Сын и Бог Дух - идея единства и нерасторжимости трех Лиц Троицы, образ триипостасного Божества, символ Евхаристии, образ божественной любви - высший идеал бытия цивилизации, к которому она, несмотря на все сложности и неоднозначность происходящих событий в ее истории, обязана стремиться и стремится в своем существовании.

Образ Божией Матери - излюбленный жанр русской иконографии - занимает в истории и культуре России особое место. В русском иконописании было создано множество икон Богоматери (более 700 наименований). Ее образ - это символ, раскрывающий богочеловеческую сущность Христа, возможность пути преображения во Христе для человека [Губарева, 2006]. В почитании образа Пресвятой Богородицы раскрывается церковноцентричность, соборность русского сознания, олицетворявшего русскую землю с Ее уделом, с Ее покровительством над ней (икона «Древо государства Российского» Симона Ушакова XVII в. и икона Божией Матери «Державная», обретенная в 1917 г., - свидетельства великого почитания Пресвятой Богородицы как покровительницы Руси).

Из всего многообразия икон Божией Матери принято выделять три основных типа: Оранта, Одигитрия, Елеуса. Они, имея свое древнее происхождение, в основном бы- 
ли присущи и русской иконографии: иконы Божией Матери «Оранта» - основные примеры: Оранта Софии Киевской, икона Великая Панагия, Мирожская икона Божией Матери, Курская-Коренная икона Божией Матери, Новгородская икона Божией Матери «Знамение», Абалакская икона Божией Матери «Знамение»; иконы Божией Матери «Одигитрия» - Иверская икона Божией Матери, Иерусалимская икона Божией Матери, икона Божией Матери Казанская, Смоленская икона Божией Матери, Тихвинская икона Божией Матери, икона Божией Матери «Троеручица», икона Божией Матери «Скоропослушница», икона Божией Матери «Споручница грешных»; иконы Божией Матери «Умиление» (Елеуса) - икона Божией Матери Владимирская, Донская икона Божией Матери, икона Божией Матери «Взыграние», икона Божией Матери «Взыскание погибших», Корсунская икона Божией Матери, Почаевская икона Божией Матери, Толгская Божия Матерь, Феодоровская икона Божией Матери, Киккская-Владимирская икона Божией Матери.

В икогографии Божией Матери, кроме основных типов Ее изображения, существуют еще так называемые избранные. К ним относят икону Божией Матери «Неопалимая Купина», икону Божией Матери «Семистрельная», икону Божией Матери «Неупиваемая Чаша», икону Божией Матери «Утоли моя печали», икону Божией Матери «Нечаянная Радость», икону Божией Матери «Прибавление ума», икону Божией Матери «Всецариияа», икону Божией Матери "Державная» и др. Данная иконография отражает в себе историю Церкви, историю христианской цивилизации, причастности русского мира к ней.

Жизнь русской цивилизации как части христианского мира в ее культурноисторической хронологии нашла свое выражение в собственном (собственное построение и осмысление календарной системы - это достояние и на сегодняшний день любой цивилизации [Бургуэн, 2006]) календаре, регламентирующем цикл жизни человека, принадлежащего к ней. Календарный цикл в большей степени в ней выражал ее метафизическое начало в совокупности взаимосвязанных культурно-исторических процессов, что обусловило в ее пространстве законченную, стройную систему регламента духовной жизни человека, временного промежутка - дня, недели, месяца, года (декретом Совнаркома о введении западноевропейского календаря 14 февраля 1918 г. по политическим мотивам многовековая календарная система была отменена). Художественно реализованный в иконографии календарный цикл дал возможность развития ряда иконографических образов, его отражающих, - икон православных праздников.

Наиболее важные из них (Воскресение Христово и 12 великих двунадесятых праздников) отражают в своих сюжетных композициях события земной жизни Иисуса Христа и Пресвятой Богородицы, Церкви, выражая метафизическую сущность христианской культуры: икона Воскресения Христова - «праздников праздника» (на пасхалии основан весь цикл христианского календаря); иконы двунадесятых неподвижных праздников (приводятся в хронологической последовательности событий): Рождество Пресвятой Богородиць - 8 сентября (21 сен. н.с.), Введение во храм Пресвятой Богородицы - 21 ноября (4 дек. н.с.), Благовещение Пресвятой Богородищы - 25 марта (7 апр. н.с.), Сретение Господне - 2 февраля (15 фев. н.с.), Успение Пресвятой Богородииы - 15 августа (28 авг. н.с.), Рождество Христово - 25 декабря (7 янв. н.с.), Богоявление или Крещение Господне - 6 января (19 янв. н.с.), Преображение Господне - 6 августа (19 авг. н.с.), Воздвижение Креста Господня - 14 сентября (27 сен. н.с.); иконы двунадесятых подвижных Господских праздников: Вход Господень в Иерусалим (празднуется за одну неделю до Пасхи), Вознесение Господне (Празднуется на 40-й день после Пасхи), Пятидесятница или День Святой Троицы (празднуется на 50-й день после Пасхи).

Икона в данном контексте - это духовно-художественный символ православия, визуальный образ русской культуры, художественный символ Руси. Наивысшего своего художественно-эстетического расцвета она достигла в развитии именно русского искусства. Русская икона и наиболее чтимые и распространенные иконографические типы - это глу- 
боко прочувствованные русским народом образы, которые воплощали в своих сюжетах идеи добра и всепрощения, любви и согласия, смирения и духовности, стойкости и готовности к самопожертвованию. Они давали русскому человеку целостное представление о мире, о Боге. В них был отражен смысложизненный вектор существования человека, общества и мира. Ее визуальный образ является эффективным способом зрительного воздействия, духовно-нравственного воспитания человека.

Осмысление русского иконографического искусства и храмостроения как самодостаточных компонентов отечественной художественной культуры позволяет рассматривать их как составляющую базиса духовной жизни народа, в котором нашли отражение основы народного самосознания, мировосприятия. Так обращение к феномену русской иконы как визуальному отражению духовной культуры может быть выражением потребности современников в осмыслении своей духовно-культурной идентичности.

Сегодня, несмотря на общемировую тенденцию стирания культурных особенностей в последние столетия, через политические преобразования и искусственное создание всемирной модели ценностей (данный трансформирующий процесс затронул все глобальное культурно-цивилизационное пространство, меняя в нем уклад жизни народов, видоизменяя ландшафтное пространство сооружениями прогрессивно-безликого техногенного дизайна) цивилизации хранят свою культурную идентичность, заложенную началом их возникновения. Они хранят свой культурно-исторический тип в собственной словесности, праве, культуре быта, искусстве. Последнее наиболее ярко проявляется в визуализации духовного начала их культур в памятниках храмового зодчества, изобразительного искусства (живописи, скульптуре) как первый шаг в познании культурно-мировоззренческой основы цивилизации, ее фундаментальных ценностей.

Современные тенденции глобальной культурной коммуникации в большей степени направлены на освоение общего мирового пространства, но в то же время локальные цивилизации стремятся сохранить свою культуру как основу своего бытия в преемственности ее духовного начала, где преемственность - залог существования любой из них в мировом пространстве.

\section{Список источников}

1. Культурология. Основы теории и истории культуры. Учебное пособие. 1996. Под. ред. И.Ф. Кефели. СПб, «Специальная литература»: 602 с.

2. Храм Христа Спасителя в Москве: Составлено по книге М.С. Мостовского, издание 1918 г. Сост. и авт. послесл. С.Н. Романова. М., 1993. Отечество, Крайтур: 96 с.

3. Шейдаев Э., Анашкевич М. 2006. Русский крест. Символика православного надглавного креста. М., АСТ, Астрель: 300 с.

4. Грэй Р., Хэнлон Д. 2000. Наглядно о религиях. Пер. с англ. П.А. Самсонова. Минск, ООО «Попурри»: 224 с.

\section{Список литературы}

1. Борзова Е.П. 2002. История мировой культуры. СПб, Лань: 672 с.

2. Бургуэн Ж. 2006. Календарь. История и современность. М., Астрель; АСТ. 144 с.

3. Буркхардт Т. 2009. Искусство ислама. Язык и значение. Таганрог, Ирби: 288 с.

4. Губарева О.В. 2006. Божия Матерь в Ее иконах. Опыт художественно-богословского анализа. М., Паломник: 160 с.

5. Емохонова Л.Г. 2007. Художественная культура буддизма. М., Издательский центр «Академия»: $96 \mathrm{c.}$

6. Кузнецов В.П. 1997. История развития формы креста. Краткий курс православной ставрографии. М., Альманах «Жизнь вечная»: 40 с.

7. Кин М. 2006. Религии мира. Харьков, «Клуб семейного Досуга»: 240 с.

8. Любимов Л.Д. 1976. Искусство Западной Европы. Средние века. Возрождение в Италии. М., Просвещение: 320 с. 
9. Новоселов М.А. 2004. Догмат и мистика в Православии, Католичестве, Протестантстве. М., Лепта-Пресс: 384 с.

10. Переслегин С.Б. 2005. Самоучитель игры на мировой шахматной доске. М., АСТ; СПб, Terra Fantastica: 619 c.

11. Самсонова Е.М., Ковальчук М.А. 2017. Индийская скульптура: от архаики до средневековья (XXII в. до н. э. - XVII в. н. э.). Хабаровск, Изд-во Тихоокеан. гос. ун-та: 200 с.

12. Спекторский Е.В. 2013. Христианство и культура. М., Центр стратегической конъюнктуры: 360 с.

13. Трубецкой Е. 1993. Умозрение в красках. Вопрос о смысле жизни в древнерусской религиозной живописи. В кн.: Философия русского религиозного искусства XVI-XX вв. Антология. Сост., общ. ред. и предисл. Н.К. Гаврюшина. М., Прогресс: 195-219.

14. Цеханская К.В. 2013. Почитание православных святынь в России. М., Паломник: 400 с.

\section{References}

1. Borzova E.P. 2002. Istoriya mirovoi kul'tury. [History of world culture]. SPb, Lan': 672 p.

2. Burguen Zh. 2006. Kalendar'. Istoriya i sovremennost'. [Calendar. History and modernity]. M., Astrel'; AST. 144 p.

3. Burkkhardt T. 2009. Iskusstvo islama. Yazyk i znachenie. [The art of Islam. Language and meaning]. Taganrog, Irbi: 288 p.

4. Gubareva O.V. 2006. Bozhiya Mater' v Ee ikonakh. Opyt khudozhestvenno-bogoslovskogo analiza. [The mother of God in her icons. Experience of artistic and theological analysis]. M., Palomnik: $160 \mathrm{p}$.

5. Emokhonova L.G. 2007. Khudozhestvennaya kul'tura buddizma [Artistic culture of Buddhism]. M., Izdatel'skii tsentr «Akademiya»: 96 p.

6. Kuznetsov V.P. 1997. Istoriya razvitiya formy kresta. Kratkii kurs pravoslavnoi stavrografii [History of the development of the cross form. Short course of Orthodox stavrography]. M., Al'manakh «Zhizn' vechnaya»: $40 \mathrm{p}$.

7. Kin M. 2006. Religii mira. [World religion]. Khar'kov, Klub semeinogo Dosuga: 240 p.

8. Lyubimov L.D. 1976. Iskusstvo Zapadnoi Evropy. Srednie veka. Vozrozhdenie v Italii. [Art Of Western Europe. Middle ages. The Renaissance in Italy]. M., Prosveshchenie: 320 p.

9. Novoselov M.A. 2004. Dogmat i mistika v Pravoslavii, Katolichestve, Protestantstve. [Dogma and mysticism in Orthodoxy, Catholicism, and Protestantism]. M., Lepta-Press: 384 p.

10. Pereslegin S.B. 2005. Samouchitel' igry na mirovoi shakhmatnoi doske. [Tutorial of the game on the world chess Board]. M., AST; SPb, Terra Fantastica: 619 p.

11. Samsonova E.M., Koval'chuk M.A. 2017. Indiiskaya skul'ptura: ot arkhaiki do srednevekov'ya (XXII v. do n. e. - XVII v. n. e.). [Indian sculpture: from the archaic to the middle ages (XXII century bc - XVII century ad)] Khabarovsk, Izd-vo Tikhookean. gos. un-ta: 200 p.

12. Spektorskii E.V. 2013. Khristianstvo i kul'tura. [Christianity and culture]. M., Tsentr strategicheskoi kon"yunktury: $360 \mathrm{p}$.

13. Trubetskoi E. 1993. Umozrenie v kraskakh. Vopros o smysle zhizni v drevnerusskoi religioznoi zhivopisi. [Speculation in colors. The question of the meaning of life in old Russian religious painting]. In: Filosofiya russkogo religioznogo iskusstva XVI-XX vv. [The philosophy of Russian religious art of XVI-XX centuries]. Anthology. Comp., General editorship and Foreword. N.K. Gavryushina. M., Progress: 195-219.

14. Tsekhanskaya K.V. 2013. Pochitanie pravoslavnykh svyatyn' v Rossii. [Veneration of Orthodox shrines in Russia]. M., Palomnik: 400 p.

\section{ИНФОРМАЦИЯ ОБ АВТОРЕ}

Лопин Роман Анатольевич, кандидат философских наук, доцент кафедры философии и теологии Белгородского государственного национального исследовательского университета, г. Белгород, Россия

\section{INFORMATION ABOUT THE AUTHOR}

Roman A. Lopin, Candidate of Philosophical Sciences, Associate Professor Department of Philosophy and Theology, Belgorod National Research University, Belgorod, Russia 